Article

\title{
Biosorption and Bioleaching of Heavy Metals from Electronic Waste Varied with Microbial Genera
}

\author{
Preetiman Kaur ${ }^{1}$, Shivani Sharma ${ }^{1, *}$, Fawziah M. Albarakaty ${ }^{2, *}$, Anu Kalia ${ }^{3, *(1)}$, Mohamed M. Hassan ${ }^{4}$ (1) \\ and Kamel A. Abd-Elsalam ${ }^{5}$ (i)
}

1 Department of Microbiology, College of Basic Sciences and Humanities, Punjab Agricultural University, Ludhiana 141004, India; kpreetiman@gmail.com

2 Department of Biology, Faculty of Applied Science, Umm Al-Qura University, Makkah Al Mukarramah P.O. Box 715, Saudi Arabia

3 Electron Microscopy and Nanoscience Laboratory, Department of Soil Science, College of Agriculture, Punjab Agricultural University, Ludhiana 141004, India

4 Department of Biology, College of Science, Taif University, P.O. Box 11099, Taif 21944, Saudi Arabia; m.khyate@tu.edu.sa

5 Plant Pathology Research Institute, Agricultural Research Centre, Giza 12619, Egypt; kamel.abdelsalam@arc.sci.eg

* Correspondence: ssharma@pau.edu (S.S.); fmbarakati@uqu.edu.sa (F.M.A.); kaliaanu@pau.edu (A.K.)

Citation: Kaur, P.; Sharma, S.; Albarakaty, F.M.; Kalia, A.; Hassan, M.M.; Abd-Elsalam, K.A. Biosorption and Bioleaching of Heavy Metals from Electronic Waste Varied with Microbial Genera. Sustainability 2022, 14, 935. https://doi.org/10.3390/ su14020935

Academic Editor: Eleni Iacovidou

Received: 11 December 2021

Accepted: 10 January 2022

Published: 14 January 2022

Publisher's Note: MDPI stays neutral with regard to jurisdictional claims in published maps and institutional affiliations.

Copyright: (C) 2022 by the authors. Licensee MDPI, Basel, Switzerland. This article is an open access article distributed under the terms and conditions of the Creative Commons Attribution (CC BY) license (https:// creativecommons.org/licenses/by/ $4.0 /)$.

\begin{abstract}
Industrialization and technological advancements have led to the exploitation of natural resources and the production of hazardous wastes, including electronic waste (E-waste). The traditional physical and chemical techniques used to combat E-waste accumulation have inherent drawbacks, such as the production of harmful gases and toxic by-products. These limitations may be prudently addressed by employing green biological methods, such as biosorption and bioleaching. Therefore, this study was aimed at evaluating the biosorption and bioleaching potential of seven microbial cultures using E-waste (printed circuit board (PCB)) as a substrate under submerged culture conditions. The cut pieces of PCB were incubated with seven microbial cultures in liquid broth conditions in three replicates. Atomic absorption spectroscopy (AAS) analysis of the culture biomass and culture filtrates was performed to evaluate and screen the better-performing microbial cultures for biosorption and bioleaching potentials. The best four cultures were further evaluated through SEM, energy-dispersive X-ray spectroscopy (EDX), and sodium dodecyl sulfate polyacrylamide gel electrophoresis (SDSPAGE) studies to identify the possible culture that can be utilized for the biological decontamination of E-waste. The study revealed the highest and differential ability of Pleurotus florida and Pseudomonas spp. for biosorption and bioleaching of copper and iron. This can be attributed to bio-catalysis by the laccase enzyme. For both P. florida and Pseudomonas spp. on the 20th day of incubation, laccase exhibited higher specific activity $(6.98 \mathrm{U} / \mathrm{mg}$ and $5.98 \mathrm{U} / \mathrm{mg}$, respectively) than other microbial cultures. The biomass loaded with $\mathrm{Cu}^{2+}$ and $\mathrm{Fe}^{2+}$ ions after biosorption was used for the desorption process for recovery. The test cultures exhibited variable copper recovery efficiencies varying between 10.5 and $18.0 \%$. Protein characterization through SDS-PAGE of four promising microbial cultures exhibited a higher number of bands in E-waste as compared with microbial cultures without E-waste. The surface topography studies of the E-waste substrate showed etching, as well as deposition of vegetative and spore cells on the surfaces of PCB cards. The EDX studies of the E-waste showed decreases in metal element content ( $\% \mathrm{wt} / \%$ atom basis) on microbial treatment from the respective initial concentrations present in non-treated samples, which established the bioleaching phenomenon. Therefore, these microbial cultures can be utilized to develop a biological remediation method to manage E-waste.
\end{abstract}

Keywords: AAS; EDX; E-waste; laccase enzyme; SDS-PAGE; SEM 


\section{Introduction}

Advanced technological devices, including mobile phones, laptops, fitness trackers, and Wi-Fi modems, have been indispensable commodities for urban and peri-urban dwellers. However, increased use and eventual disuse, followed by the discarding of these devices into landfills, has brought another environmental concern to the forefront: electronic waste (E-waste) [1]. E-waste consists primarily of various components of discarded electronic products, such as printed circuit boards (PCBs), printers, photocopiers, television sets, refrigerators, and mobile phones that are broken beyond repair or are technologically obsolete [2]. It consists of large quantities of heavy metals, including arsenic, antimony, cadmium, chromium, copper, iron, lead, mercury, zinc, and certain organic contaminants [3]. E-wastes are non-biodegradable, and hence get accumulated in the soil and water, causing a serious threat to living organisms and the ecosystem. Most of these heavy metals, even at very low concentrations, are highly toxic and impose serious damage to living organisms by entering the food chain [4]. As the higher internet penetration has led to increased Ewaste generation in the developing countries, the problem is compounded due to financial constraints and lack of environmental regulations in these countries leading to dumping of the E-waste in landfills without proper treatment [5]. To save the ecosystem from getting contaminated, there is a dire need to create awareness for extracting useful metals present in the E-waste.

Different physicochemical approaches, such as incineration, landfill dumping, chemical oxidation, reduction, adsorption, and precipitation have been adopted to minimize the effects of E-waste but these methods possess certain drawbacks and limitations [6-14] (Supplementary Table S1). Therefore, there is a strong need to identify alternate efficient, cost-effective, and eco-friendly methods for extracting metals from E-waste. The biological E-waste management approach involves the conversion of toxic substances to non-toxic forms by utilizing natural metabolic bioprocesses of microorganisms [15]. Microbes are capable to extract the heavy metals from complex compounds such as dye molecules and coordinate complexes [16]. They possess diverse and effective metabolic pathways, which are used as electron acceptors during fermentation processes [17].

Biosorption and bioleaching are some of the main strategies that involve the ability of microbes to adsorb and recover heavy metals $[18,19]$. These processes require interaction between living or dead microorganisms and metals (as ions, salts, compounds, complexes) in the systems to clean up the polluted sites [20]. Both living and dead microbial biomass can be used for the biosorption of metal ions. Microbial cell walls contain diverse components that have different functional groups, such as imidazole, thioether, sulfonate, carbonyl, sulfhydryl, carboxyl, phosphodiester, phenolic, imine, and phosphate groups that are required for sequestering metal ions present in the E-waste [18]. Different bacteria (Thiobacillus spp., Pseudomonas spp., Bacillus spp.) and fungi (Aspergillus spp., Penicillium spp., Pleurotus florida, Lentinula edodes, Ganoderma lucidum, and Trametes versicolor) were evaluated for the remediation of E-waste. One of the studies found that about $100 \%$ of copper could be recovered in just $2 \mathrm{~h}$ from $5 \mathrm{~g} / \mathrm{L}$ PCBs through the bioleaching phenomenon by the application of a bacteria-free cultural supernatant (Leptospirillum ferriphilum and Sulfobacillus thermosulfidooxidans) [21]. Similarly, Trivedi et al. [22] reported in their study that there was a marginal increase in the bioleaching of $\mathrm{Cu}(5 \%)$ and $\mathrm{Ni}(4 \%)$ metals from PCBs by the Aspergillus culture. Therefore, microorganisms do exhibit the ability to convert solid metallic compounds present in the E-waste to their soluble and extractable forms [23].

Bacteria are considered important absorbing agents due to their unique size, rapid growth under controlled conditions, and adaptability toward environmental conditions [24]. While fungal hyphae act as effective accumulators of heavy metals due to their large surface area-volume ratio [25]. Microbes also possess certain characteristics that allow them to degrade oxidoreductase enzymatic complexes, such as the laccase enzyme complex, which plays a unique role in diverse remediation applications. Microbes require laccase as a prominent multicopper oxidase enzyme involved in the oxidation of phenolic compounds, such as liganols and flavanoids. The laccase enzyme system exists both among prokaryotic 
bacteria (Pseudomonas aeruginosa, Streptomyces spp.) and eukaryotic fungi (Pleurotus florida, Trametes versicolor, Aspergillus niger, Ganoderma lucidum, and Lentinula edodes). Due to its substrate non-specificity, it can help in the detoxification of toxic compounds via oxidative coupling [16]. Thus, these microbial biocatalytic agents play a vital role in leaching different metals from E-waste through the mechanism of biosorption. This mechanism involves the sorption of metal species inside the cell to help with the remediation of heavy metal ions from E-waste in a cost-effective and eco-friendly manner. Hence, the present study aimed to use certain microorganisms with laccase-dependent bio-catalysis potential to accomplish the bioleaching and biosorption of metal ions from E-waste. As laccases are efficient on a wide range of substrates without cofactors, in most cases, the addition of $\mathrm{Cu}^{2+}, \mathrm{Cd}^{2+}$, $\mathrm{Ni}^{2+}, \mathrm{Mo}^{2+}$, and $\mathrm{Mn}^{2+}$ ions increase the activity of laccases [26]. Therefore, the secretion of this enzyme extracellularly in the presence of E-waste (metal ion source) can be used as an indirect and easy approach to compare the bioleaching of metal ions before and after the treatment of E-waste with different laccase-producing microorganisms (Supplementary Table S2) [27-29]. This approach can provide a more efficient remediation strategy for metal ion recovery from E-waste.

\section{Materials and Methods}

\subsection{Collection of E-Waste Samples}

Electronic waste, including printed circuit boards (PCBs) of out-of-use computers, was collected from a local recycling unit and dump yards of electronic waste located at Kochar Market, Ludhiana, India. These PCBs were thoroughly washed and cleaned to remove dust and any other adhering deposits.

\subsection{Treatment of the E-Waste for Metal Content Analysis}

The metal element content of each PCB was quantified by performing an AAS analysis of the PCBs. Each PCB was incubated with $10.0 \mathrm{M} \mathrm{NaOH}$ solution for $48 \mathrm{~h}$ to remove the chemical coating. This was followed by washing under running water to eliminate the solder. Later, contents were dried in a tray dryer for $40 \mathrm{~min}$ and milled in an impact pulverizer to obtain the powder. This powder was sieved through a $120 \mu \mathrm{m}$ pore size filter for estimation of the number of metal elements present in the untreated E-waste using AAS [30].

\subsection{Screening of Microorganisms for E-Waste Remediation}

a. Procurement of microbial cultures: Seven microbial cultures, viz. Lentinus edodes, Pleurotus florida, Ganoderma lucidum, Aspergillus niger, Trametes versicolor, Streptomyces spp., and Pseudomonas spp., were analyzed for their biological remediation potential. These microbial cultures were procured from the culture repository of the Department of Microbiology, Punjab Agricultural University (PAU), Ludhiana. All the experiments were performed at Dr. H.S. Garcha Mushroom Laboratories, PAU, Ludhiana.

b. Preparation of the culture media: The PCB samples were cut into small pieces $(25.0 \times 15.0 \times 1.1 \mathrm{~mm})$. A known weight of the PCB $(5.0 \mathrm{~g})$ was washed $4-5$ times with distilled water, followed by ethanol washing, and then it was placed in liquid minimal broth (mushroom minimal media (for fungal cultures) and bacterial minimal media (M9 media; for bacterial cultures)). The composition of the mushroom minimal media (in $\mathrm{g} \mathrm{L}^{-1}$ ) was: L-asparagine (1.60), D-glucose (20.0), magnesium sulfate heptahydrate (0.5), di-potassium hydrogen phosphate (1.0), potassium dihydrogen ortho-phosphate (0.46), and thiamine hydrochloride (0.125); $\mathrm{pH}$ 6.5. The bacterial minimal media composition had the following components (in $\mathrm{g} \mathrm{L}^{-1}$ ): glucose (20), disodium hydrogen phosphate heptahydrate (33.9), potassium dihydrogen orthophosphate (15.0), ammonium chloride (5.0), and sodium chloride (2.5); $\mathrm{pH}$ 7.2. The $\mathrm{pH}$ of the media used for the growth of the bacterial and fungal cultures were kept 
at 6.5 and 7.2, respectively. The media were autoclaved at a temperature of $121^{\circ} \mathrm{C}$ using steam under pressure (15 pounds per inch square) for 20 min duration.

c. Laccase activity: The sterilized broth containing the known quantity of the E-waste ( $5 \mathrm{~g} \mathrm{~L}^{-1}$ of the broth media) was inoculated with different microorganisms and incubated in a rotary shaker incubator at an appropriate temperature (fungal cultures $25 \pm 2{ }^{\circ} \mathrm{C}$; bacterial cultures $27 \pm 2{ }^{\circ} \mathrm{C}$ ). Control broth (without E-waste) was also inoculated with the microbial cultures. The specific activity of the laccase enzyme was performed using buffered guaiacol and measured at intervals of 4 days up to 24 days of incubation [31].

\subsection{Biosorption and Bioleaching Experiment}

The bioleaching potential of the cultures was assayed on the 8th day of incubation, while the biosorption potential of the microbial cultures was evaluated on the 20th day of incubation. The specific days of incubation for the bioleaching and biosorption assays were identified based on the maximum laccase activity.

Broth $(1 \mathrm{~mL})$ was inoculated with seven microbial cultures in different flasks, along with a control containing leached metal ions, was digested for $24 \mathrm{~h}$ with $20 \mathrm{~mL}$ of aqua-regia solution (35\% $\mathrm{HCl}$ and $70 \%$ high-purity $\mathrm{HNO}_{3}$ in a 3:1 ratio). The centrifugation of the digested solution was performed for $15 \mathrm{~min}$ at $5000 \mathrm{rpm}$. Then, the digested solution was filtered through a $0.45 \mu \mathrm{m}$ membrane filter.

A biosorption assay was performed by weighing the dried biomass $(1.0 \mathrm{~g})$ of all microbial cultures. The samples were digested with $15.0 \mathrm{~mL}$ of aqua regia $(35 \% \mathrm{HCl}$ and $70 \%$ high-purity $\mathrm{HNO}_{3}$ in a 3:1 ratio) at $70{ }^{\circ} \mathrm{C}$ till the solution became transparent. The resulting solution was filtered through Whatman filter paper no. 42 and diluted using deionized water. Sample solutions were analyzed for concentrations of $\mathrm{Cu}$ and Fe.

Element $(\mathrm{mg} / \mathrm{kg})=(\mu \mathrm{g} / \mathrm{mL}$ in sample solution $) \times($ dilution factor $) \times($ total volume of solution)/(sample weight in $\mathrm{kg}$ ).

\subsection{Desorption Experiment}

After biosorption, the copper and iron ions retained by the microbial biomass were desorbed by treatment with $50.0 \mathrm{~mL}$ of $0.05 \mathrm{M}$ nitric acid. The samples were stirred in an orbital shaker at $160 \mathrm{rpm}$ for $24 \mathrm{~h}$. The mixture was filtered and washed with distilled water and the filtrate was used for determining the concentration of desorbed copper and iron ions.

The desorption of copper and iron $\left(\mathrm{Q}_{\mathrm{de}}\right)$ and the rate of desorption $(\%)$ were calculated using the following equation [32]:

$$
\mathrm{Q}_{\mathrm{de}}\left(\frac{\mathrm{mg}}{\mathrm{kg}}\right)=\mathrm{C}_{1} \mathrm{~V} / \mathrm{W}
$$

Rate of desorption $(\%)=\frac{\mathrm{Q}_{\mathrm{de}}}{\mathrm{Q}_{\mathrm{e}}} \times 100$, where $\mathrm{Q}_{\mathrm{de}}$ is the amount of desorbed $\mathrm{Cu}^{+2}$ and $\mathrm{Fe}^{2+}$ ions ( $\left.\mathrm{mg} \mathrm{kg}^{-1}\right), \mathrm{V}$ is the volume of desorption solution ( $\left.\mathrm{L}\right), \mathrm{C}_{1}$ represents the metal ion concentration present in the filtrate $\left(\mathrm{mg} \mathrm{L}^{-1}\right), W$ is the quantity of dry biomass $(\mathrm{kg})$, and $Q_{e}$ is the amount of sorption of metal ions.

\subsection{Morphological and Protein Profiling Alterations of PCBs Post Microbial Incubation for Screened Microbial Isolates}

a. Electron microscopy analysis: The scanning electron microscopy (SEM) analysis of the PCB samples in minimal broth inoculated with different microbial cultures involving Pleurotus florida, Trametes versicolor, Aspergillus niger, and Pseudomonas spp. was performed after 20 days of incubation. Post 20 days of incubation, the PCB samples were removed from the minimal broth, washed three times with phosphate buffer saline (PBS) to remove any loosely adhering substances, soaked in $4 \%$ glutaraldehyde for $2 \mathrm{~h}$, immersed in $3 \%$ paraformaldehyde for $1 \mathrm{~h}$, successively dehydrated in 
ethanol series, and dried out overnight. The processed samples were analyzed using Environmental SEM (Quanta-200, FEI, Hilsboro, Oregon, US) at $10 \mathrm{kV}$ accelerating voltage to obtain SE micrographs.

b. Protein profiling of microbial cultures through sodium dodecyl sulfate-polyacrylamide gel electrophoresis (SDS-PAGE): Based on the AAS results, the best four screened cultures were used for protein profiling via SDS-PAGE. These cultures were inoculated in the liquid medium with E-waste and without E-waste (as control). In the case of bacteria on the 20th day, the microbial biomass was separated via centrifuging the culture contents at $6000 \mathrm{rpm}$ for $30 \mathrm{~min}$. For fungal cultures, the biomass was collected via centrifuging the contents at $3000 \mathrm{rpm}$ for $20 \mathrm{~min}$. The SDS-PAGE was performed according to the method described by Laemmli for estimating the expression of proteins with a $12 \%$ polyacrylamide gel [33].

\subsection{Statistical Analysis}

All the experiments including the laccase activity, bioleaching, and biosorption studies were performed using three replicates. The data were analyzed by using a proc generalized linear model in SAS software (Version 9.2, Cary, NC, USA). The average mean and standard error were calculated for the AAS studies.

\section{Results}

\subsection{Metal Content Analysis of PCB}

In this study the metal contents of the PCB samples were estimated through AAS is presented in Table 1. The most abundant elements included copper and iron elements, with contents in a range of 268.6 and $179.4 \mathrm{mg} \mathrm{g}^{-1}$, respectively, which were similar to already reported concentrations ( $\mathrm{Cu}: 275.5 \mathrm{mg} \mathrm{g}^{-1}$, Fe: $63.7 \mathrm{mg} \mathrm{g}^{-1}$ [34]). But Waldir et al. [35] have sparingly reported the occurrence of elements other than $\mathrm{Cd}, \mathrm{Ag}$ and $\mathrm{Pb}$. Furthermore, another report by Shah et al. [36] indicated the predominance of copper $\left(360 \mathrm{mg} \mathrm{g}^{-1}\right)$ and iron $\left(10.50 \mathrm{mg} \mathrm{g}^{-1}\right)$ elements. However, other reports presented a predominance of metals elements other than copper and iron. The variability in the metal content concentrations may be attributed to the type of PCB E-waste sample, which may have been different in these studies.

Table 1. Metal content analysis (concentration in $\mathrm{mg} \mathrm{g}^{-1}$ ) of PCBs and its comparison with the published reports.

\begin{tabular}{cccccc}
\hline Metals & $\begin{array}{c}\text { Khatri et al. } \\
{[34]}\end{array}$ & $\begin{array}{c}\text { Waldir et al. } \\
{[35]}\end{array}$ & $\begin{array}{c}\text { Shah et al. } \\
{[36]}\end{array}$ & $\begin{array}{c}\text { Szałatkiewicz } \\
{[37]}\end{array}$ & $\begin{array}{c}\text { Present } \\
\text { Study }\end{array}$ \\
\hline $\mathrm{Cu}$ & 275.5 & - & 360 & 14.6 & $268.6 \pm 10.2$ \\
\hline $\mathrm{Zn}$ & 17.85 & - & 7.96 & - & $7.5 \pm 2.2$ \\
\hline $\mathrm{Ni}$ & 19.55 & - & 8.55 & 1.65 & $10.20 \pm 0.0$ \\
\hline $\mathrm{Fe}$ & 63.7 & - & 10.50 & 4.79 & $179.4 \pm 16.8$ \\
\hline $\mathrm{Cd}$ & 0.02 & 22.0 & - & - & $\mathrm{ND}$ \\
\hline $\mathrm{Au}$ & 0.08 & - & 0.10 & 0.0205 & $\mathrm{ND}$ \\
\hline $\mathrm{Ag}$ & 0.08 & 0.02 & 0.28 & 0.045 & $\mathrm{ND}$ \\
\hline $\mathrm{Co}$ & 0.42 & - & - & - & $0.13 \pm 0.02$ \\
\hline $\mathrm{Pb}$ & 0.88 & 133.0 & 12.07 & 2.96 & $\mathrm{ND}$ \\
\hline $\mathrm{Pd}$ & 0.08 & - & 0.64 & 0.022 & $\mathrm{ND}$ \\
\hline
\end{tabular}

ND: not detected due to concentrations below the detection limit.

\subsection{Screening for Identification of Potential Microbial Cultures}

\subsubsection{Laccase Activity}

Most of the laccases are extracellular; hence, it is easy to identify and purify these enzymes [38]. The laccases get activated in the presence of metal elements, particularly 
$\mathrm{Cu}$ [39]. A broth study involving the estimation of the laccase enzyme activity was carried out for enumerating the effect of leached metal ions on enzymatic activity. Therefore, in this study, E-waste served as an inducer for enhancing the laccase activity due to the presence of metal elements in the PCB cards. Among the fungal and bacterial genera, Pleurotus florida and Pseudomonas spp. exhibited the highest laccase activities of 6.98 and $5.98 \mathrm{U} / \mathrm{mg}$ of protein, respectively, on the 20th day of incubation in E-waste supplemented minimal medium (Figure 1). Overall, there was an approximately 2.9-fold increase in the laccase activity of the microbial cultures in the presence of PCBs up to 20 days of incubation.

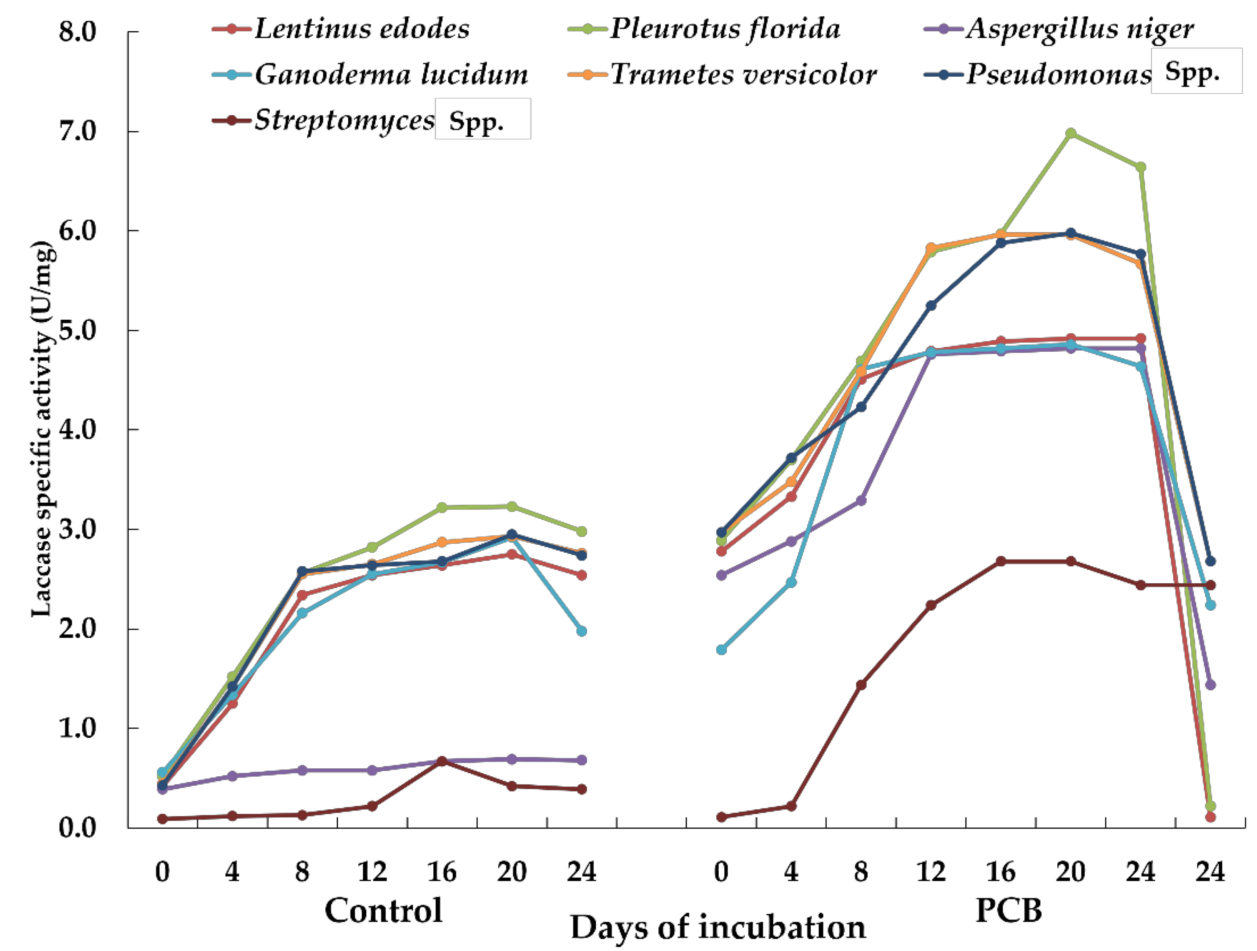

Figure 1. Changes in the laccase specific activity $(\mathrm{U} / \mathrm{mg})$ of different microbial cultures at different time intervals of incubation with the printed circuit board.

\subsubsection{Biosorption and Bioleaching Assay}

The AAS analysis was performed to identify the extent of change in the concentrations of different metal ions in the presence and absence of microbial cultures in the broth (bioleaching) and the biomass (biosorption). An increase in the concentration of metals in the treated broth reflected the leaching of metals from the E-waste. Pleurotus florida showed the maximum bioleaching of copper $\left(44.30 \mathrm{mg} \mathrm{L}^{-1}\right)$, followed by Pseudomonas spp. (42.06 $\left.\mathrm{mg} \mathrm{L}^{-1}\right)$. Pseudomonas spp. showed the maximum bioleaching for iron (46.33 $\mathrm{mg} \mathrm{L}^{-1}$; Table 2). Biosorption of copper and iron was also analyzed using elemental analysis of the mycelium/microbial growth through AAS on the 20th day of incubation. Pleurotus florida and Pseudomonas spp. followed the same trend as observed in the bioleaching of broth studies (Table 2). Pleurotus florida biosorbed $97.26 \mathrm{mg} \mathrm{kg}^{-1}$ of copper and $94.13 \mathrm{mg} \mathrm{kg}^{-1}$ of iron, whereas Pseudomonas showed increased Fe biosorption as compared to copper, i.e., 98.00 and $96.20 \mathrm{mg} \mathrm{kg}^{-1}$, respectively. Overall, approximately 35\% of the biosorption of $\mathrm{Cu}$ and $30 \%$ biosorption of Fe were performed by the best-screened microbes (P. florida and Pseudomonas spp.). 
Table 2. Characterization of different microorganisms for copper and iron from E-waste using atomic absorption spectroscopy.

\begin{tabular}{|c|c|c|c|}
\hline Elements & Microorganisms & $\begin{array}{c}\text { Bioleaching }\left(\mathrm{mg} \mathrm{L}^{-1}\right) \\
\text { (Broth Filtrate on } \\
\text { 4th Day) }\end{array}$ & $\begin{array}{l}\text { Biosorption (mg kg-1, } \\
\text { Microbial Growth on } \\
\text { 20th Day) }\end{array}$ \\
\hline \multirow[t]{7}{*}{ Copper } & Lentinus edodes & $12.46 \pm 1.12^{\mathrm{e}}$ & $56.80 \pm 0.96^{\mathrm{d}}$ \\
\hline & Pleurotus florida & $44.30 \pm 0.74^{\mathrm{a}}$ & $97.26 \pm 0.98^{a}$ \\
\hline & Ganoderma lucidum & $20.93 \pm 0.4^{\mathrm{d}}$ & $49.40 \pm 0.56^{\mathrm{e}}$ \\
\hline & Aspergillus niger & $36.13 \pm 0.02^{\mathrm{c}}$ & $73.66 \pm 0.02^{c}$ \\
\hline & Trametes versicolor & $41.26 \pm 0.82^{b}$ & $76.66 \pm 0.02^{b}$ \\
\hline & Streptomyces spp. & $11.30 \pm 0.26^{\mathrm{f}}$ & $47.50 \pm 1.34^{\mathrm{e}}$ \\
\hline & Pseudomonas spp. & $42.06 \pm 0.20^{b}$ & $96.20 \pm 0.55^{\mathrm{a}}$ \\
\hline \multirow[t]{7}{*}{ Iron } & Lentinus edodes & $21.60 \pm 0.26^{\mathrm{e}}$ & $62.76 \pm 0.08^{\mathrm{e}}$ \\
\hline & Pleurotus florida & $43.13 \pm 0.88^{b}$ & $94.13 \pm 0.98^{b}$ \\
\hline & Ganoderma lucidum & $13.96 \pm 0.4^{g}$ & $57.86 \pm 0.74^{\mathrm{f}}$ \\
\hline & Aspergillus niger & $34.10 \pm 0.02^{\mathrm{c}}$ & $70.93 \pm 0.18^{\mathrm{d}}$ \\
\hline & Trametes versicolor & $32.10 \pm 0.17^{\mathrm{d}}$ & $82.13 \pm 0.02^{c}$ \\
\hline & Streptomyces spp. & $18.06 \pm 0.66^{\mathrm{f}}$ & $43.96 \pm 0.12^{g}$ \\
\hline & Pseudomonas spp. & $46.33 \pm 0.52^{\mathrm{a}}$ & $98.00 \pm 0.08^{a}$ \\
\hline
\end{tabular}

Mean values within columns with the different alphabets or letter(s) $\left.{ }^{(a-g}\right)$ were significantly different according to a standard error where $p<0.05$. Incubation period: 20 days.

\subsubsection{Desorption of Copper and Iron Ions by Different Microbial Cultures}

The biomass loaded with $\mathrm{Cu}^{2+}$ and $\mathrm{Fe}^{2+}$ ions after biosorption was used for the desorption process. The test cultures exhibited variable copper recovery efficiencies varying between $10.5 \%$ and $18.0 \%$ in the following order: P. florida $(18.0 \%)>$ Pseudomonas spp. $(16.6 \%)>$ A. niger $(15.2 \%)>$ Streptomyces spp. $(15.0 \%)>$ G. lucidum $(14.6 \%)>$ T. versicolor $(13.2 \%)>$ L. edodes $(10.5 \%)$, as shown in Table 3 . Therefore, the maximum copper recovery efficiency was recorded for Pleurotus florida, followed by Pseudomonas spp. Similar to the copper recovery efficiency, the highest recovery efficiency for iron was also obtained for these two cultures. However, the order was reversed, with Pseudomonas spp. (13.6\%) showing maximum value, followed by P. florida (12.4\%). Overall, all the test cultures exhibited iron recovery efficiency varying from 9.0 to $13.6 \%$.

Table 3. Desorption of $\mathrm{Cu}^{2+}$ and $\mathrm{Fe}^{2+}$ ions using microbial cultures.

\begin{tabular}{ccc}
\hline \multirow{2}{*}{ Microorganisms } & \multicolumn{2}{c}{ Rate of Desorption of Elements (\%) } \\
\cline { 2 - 3 } & Copper & Iron \\
\hline Lentinus edodes & 10.5 & 9.0 \\
Pleurotus florida & 18.0 & 12.4 \\
Ganoderma lucidum & 14.6 & 10.1 \\
Aspergillus niger & 15.2 & 11.2 \\
Trametes versicolor & 13.2 & 12.0 \\
Streptomyces spp. & 15.0 & 9.4 \\
Pseudomonas spp. & 16.6 & 13.6 \\
\hline
\end{tabular}

3.3. Morphological and Protein Profile Alterations in the Screened Microbial Genera

\subsubsection{Scanning Electron Microscopy Analysis}

The alteration in the surface topography of the PCB E-waste can be considered as an effective tool for monitoring the heavy metal adsorption on the cell surface. Therefore, SEM studies of the surface of the electronic waste samples after incubation with different microbial cultures can show colonization of the test cultures to form adsorbing biofilm-like structures and the extent of etching of the sample PCB card surfaces. The SE micrographs indicated the differential ability of the inoculated cultures regarding the occurrence of various vegetative and spores cells in comparison to the sample surface in the un-inoculated 
control treatment (Figure 2). The un-inoculated control (Figure 2a) exhibited no microbial growth on the surface of the computer printed circuit boards (PCB) samples, as indicated by the appearance of a uniform, relatively smooth surface topography with an absence of aggregates or deposits, pits, or depressions on the surface of the E-waste sample. The conspicuous occurrence of rod-shaped (Pseudomonas spp.) cells can be seen in Figure $2 \mathrm{~b}$. These cells appear to be embedded in the extracellular matricular substance that could have originated due to the production of extracellular polysaccharides by the bacteria required for the attachment of the cells to the surface of the E-waste sample. Among the fungal cultures evaluated for the growth and etching of E-waste samples, the sample surface of the prominent cultures, i.e., Aspergillus niger, Pleurotus florida, and Trametes versicolor, were observed under SEM. The PCB sample incubated with the Aspergillus niger fungal culture exhibited a sample surface studded with fungal spores. The sample surface also indicated the occurrence of hyphal network surrounded by spores (broken arrows in panel c of Figure 2) and conspicuous granular deposits (solid arrow in panel c of Figure 2), indicating biosorption followed by precipitation of the heavy metals.

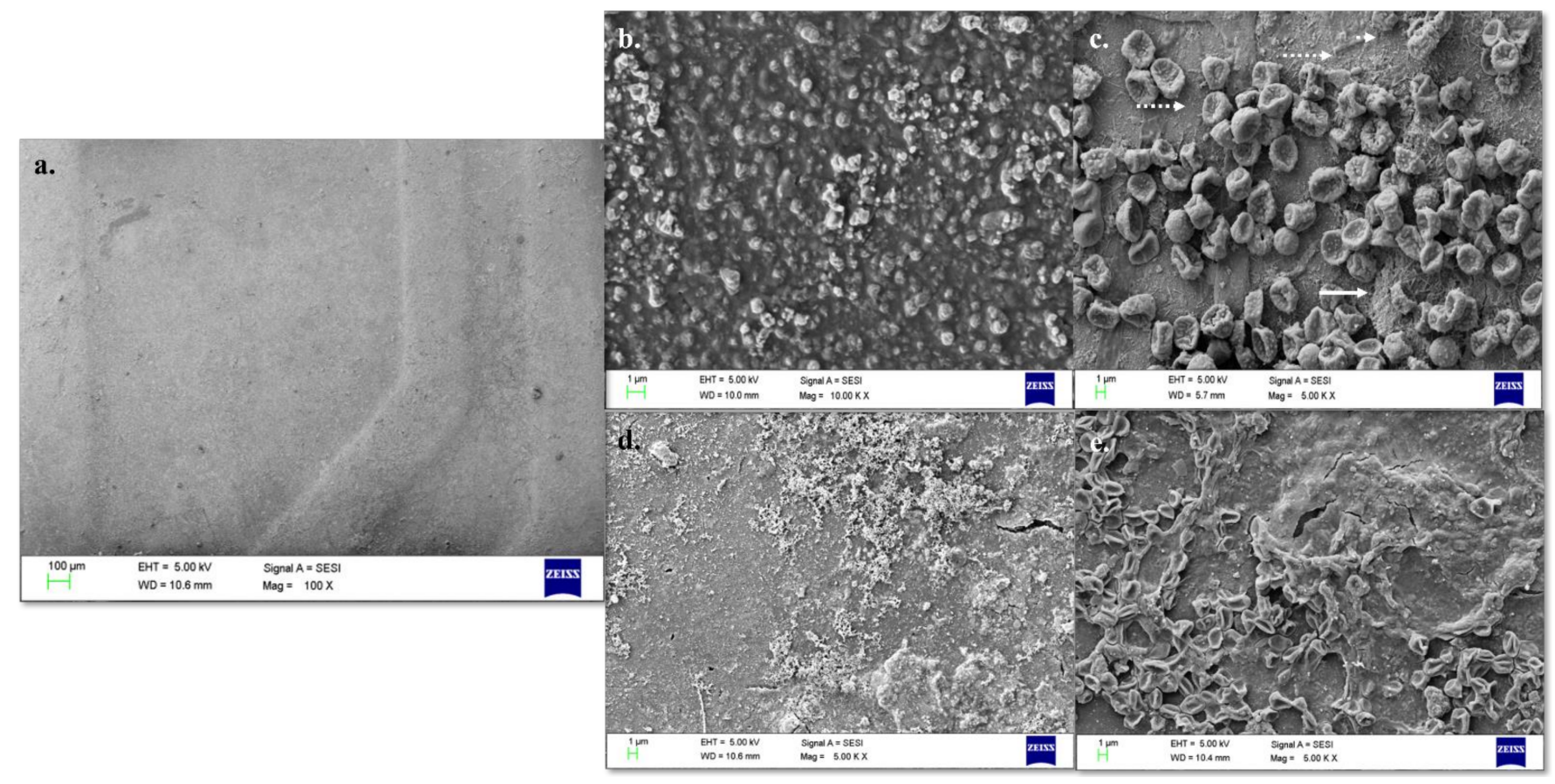

Figure 2. Scanning electron microscopy indicating the colonization of the surface of the electronic waste (PCB) by different microbial cultures after 20 days after incubation: (a) untreated control PCB, (b) Pseudomonas sp. PCB, (c) Aspergillus niger PCB, (d) Pleurotus florida PCB, and (e) Trametes versicolor PCB. * Solid arrow in panel (c) indicates a mycelial mass surrounded by the spores, while the broken arrows indicate the granular deposits formed due to leaching and precipitation of the heavy metal components of the computer PCB samples.

\subsubsection{SEM-Energy-Dispersive X-ray Spectroscopy (SEM-EDX) Analysis}

SEM-EDX elemental analysis revealed decreased amounts of certain elements (in percent atom or percent weight) due to incubation of E-waste with different types of microbial cultures in comparison to un-inoculated samples. The presence of prominent peaks of copper $(\mathrm{Cu})$ and iron (Fe) in the EDX report of untreated PCB samples (Figure 3a) can be noticed. However, the absence of these peaks in PCB treated with Pseudomonas spp. was noted (Figure 3b). The EDX studies for PCBs inoculated with Aspergillus niger, Pleurotus florida, and Trametes versicolor showed that copper $(\mathrm{Cu})$, iron $(\mathrm{Fe})$, and lead $(\mathrm{Pb})$ concentrations were decreased from their respective initial concentrations present in nontreated samples. Decreased concentrations of these metal ions were further noticed from the absence of prominent peaks in the EDX spectra report (Figure 3c-e), which might 
have occurred due to the detoxification process affected by the abovementioned fungal cultures through bioleaching of these metal ions, followed by the biosorption of leached ions. Biosorption might have occurred through ion exchange or the adsorption of metal.

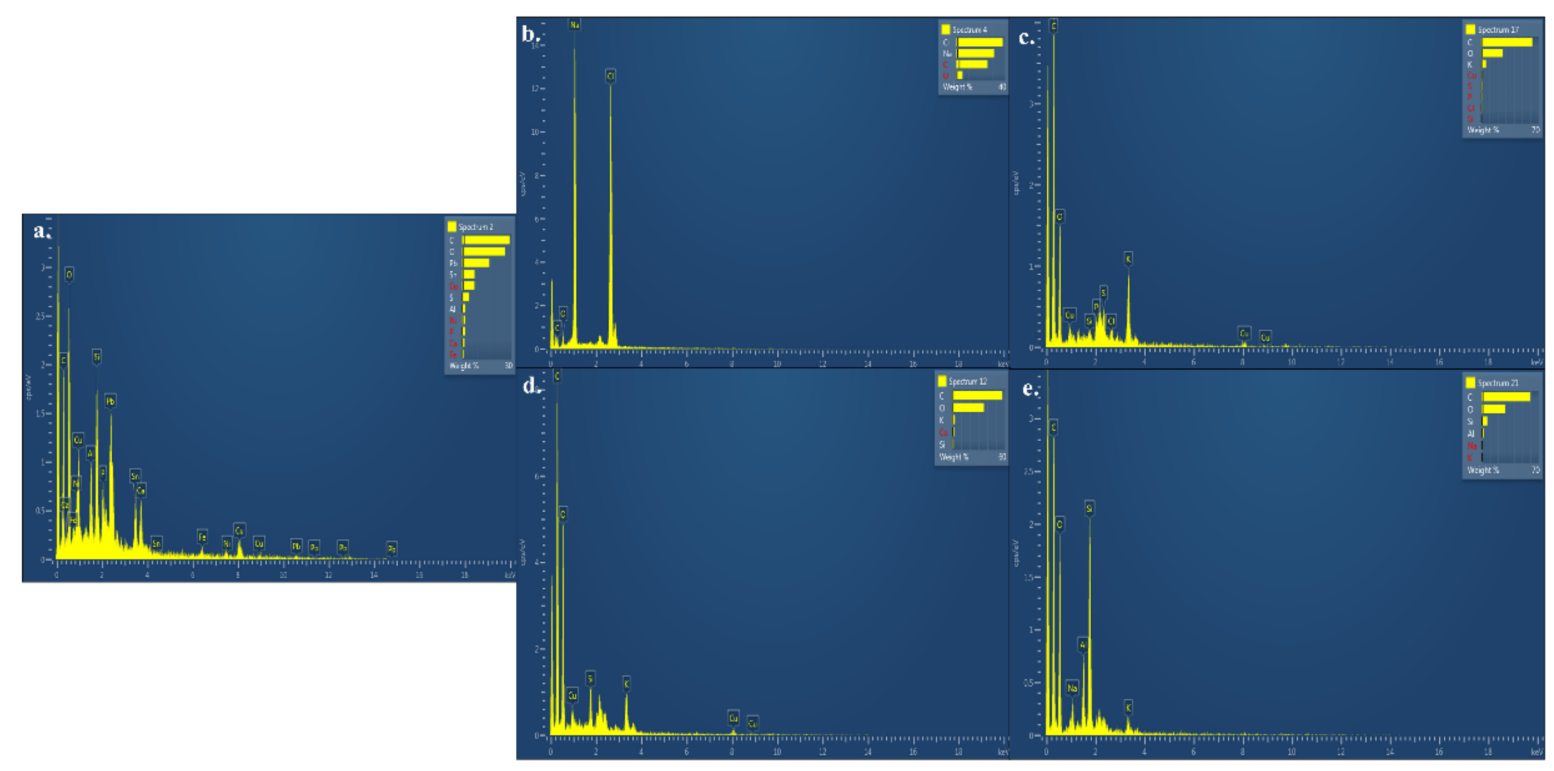

Figure 3. Energy-dispersive $X$-ray spectroscopy (EDX) analysis of the bioleaching of metal ions by different microbial cultures: (a) untreated control PCB, (b) Pseudomonas sp. PCB, (c) Aspergillus niger PCB, (d) Pleurotus florida PCB, and (e) Trametes versicolor PCB.

\subsubsection{Protein Profiling through SDS-PAGE}

The protein expression profiling of the best screened microbial cultures (Pleurotusflorida, Trametes versicolor, Aspergillus niger, and Pseudomonas spp.) from the previous experiment was carried out through SDS-PAGE. The SDS-PAGE protein banding pattern showed variations in the expressions of proteins in the treated (with E-waste) and untreated (without E-waste) broth cultures with molecular weight ranging from 14.3 to $97.4 \mathrm{kDa}$ (Figure 4). Pleurotus florida showed the maximum number of bands (12 bands) in the presence of E-waste in comparison to untreated culture (without E-waste), while Aspergillus niger and Trametes versicolor showed 10 prominent bands when treated with E-waste (Figure 4).

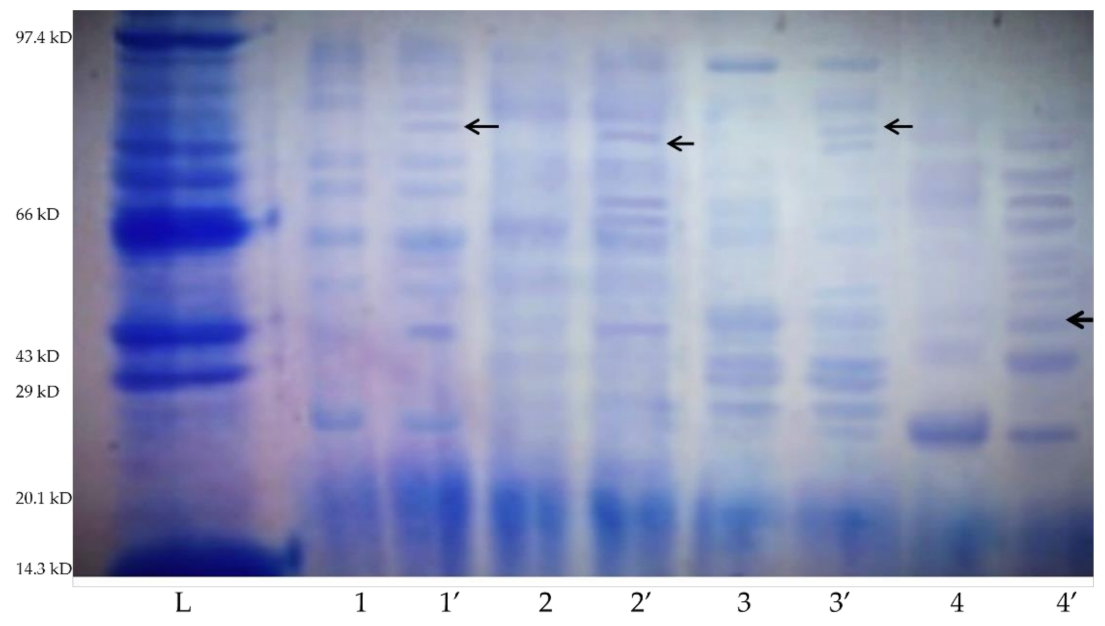

Figure 4. SDS-PAGE for protein profiling of treated and untreated microbial cultures. L denotes ladder, lane 1-Pleurotus florida, lane 1'-Pleurotus florida (treated with E-waste), lane 2-Aspergillus niger, lane 2'-Aspergillus niger (treated with E-waste), lane 3-Trametes versicolor, lane 3'-Trametes versicolor (treated with E-waste), lane 4-Pseudomonas spp., lane 4'-Pseudomonas spp. (treated with E-waste). 


\section{Discussion}

E-waste contains a high amount of environmentally toxic heavy metal elements [40-43] that can be leached and extracted by microorganisms. Microbes exhibit physiological diversity due to production of diverse enzymes, including the laccase enzyme complex. This enzyme requires metal ions as cofactors; hence, the biosorption of these metals stimulates enzyme production. In a broth culture study on Pleurotus ostreatus, Zhu et al. [44] observed $>80$-fold enhancement in the laccase activity in the presence of copper ions with the highest laccase activity ( 8533.33 to $1228.94 \mathrm{U} / \mathrm{mL}$ ) on the 13th day of cultivation compared with the control treatment. Therefore, the enhancement in the enzyme activity might be due to the leaching of metals via oxidation from E-waste in response to metabolic activities of the inoculated microbes over the incubation period. Moreover, the binding of certain metals with enzymes can cause conformational changes in the substrate, which would further enhance the rate of reaction [45]. In our study, E-waste did not act as a substrate for the laccase enzyme; rather, E-waste provided the metal ions as inducers, which played a significant role as cofactors. The present study showed that on the 20th day of incubation, there was a marginal increase in the laccase-specific activity of every microbial culture in comparison to the control. Similarly, Neifar et al. [46] also reported the highest laccase activities (6400 U) post 13 days of incubation in wheat bran medium supplemented with $2.0 \mathrm{mM}$ copper sulfate by fungus Fomes fomentarius. In the present study, the results showed that Pleurotus florida $(6.98 \mathrm{U} / \mathrm{mg}$ ) and Pseudomonas spp. (5.98 U/mg) exhibited greater capacity to express more enzyme activity in the presence of E-waste as compared with other microbial cultures.

The highest laccase enzyme elicitation occurred in presence of copper in white-rot fungi [47]. Copper supplementation (up to $0.5 \mathrm{mM}$ ) increased the laccase expression in Pleurotus sajor-caju when grown on industrial effluents [48]. Under solid-state fermentation (SSB) in Trametes versicolor, $\mathrm{Cu}$ supplementation in the basal medium induced laccase production [49]. Similarly, in this research, Pleurotus florida and Pseudomonas spp. exhibited increased laccase activity of 6.98 and $5.98 \mathrm{U} / \mathrm{mg}$, respectively, on the 20th day of incubation in E-waste supplemented minimal medium because the E-waste here acted as the source of metal ions, which helped with boosting the enzyme activity.

The study also revealed that the laccase activity depreciated after the 20th day of incubation, indicating the cellular toxicity caused by the metal cations leached from the PCB samples. Further, it can be argued that, as the old cells cannot withstand the toxic effect of certain inducers (such as heavy metals), the enzyme activity started decreasing [50]. Not only $\mathrm{Cu}$, other metal ions, such as manganese (Mn) and zinc (Zn), were also observed to stimulate laccase activity [51]. Copper and cadmium, in addition to binding to certain acid residues in enzyme molecules, can cause oxidative stress to proteins by inducing the production of reactive oxygen species, such as superoxide radicals [52], which could be one of the major reasons for a decrease in the enzyme activity. Thus, it can be concluded from this study that the tested microorganisms with their unique laccase activity possessed an ability to extract or transform a variety of metal ions present in E-waste.

With increased metal ion leaching in the broth, the phenomenon of both bioleaching and biosorption of metal ions increased, as shown in Table 2. This showed that there was enough metal concentration in the broth, which was taken up as nutrients and an energy source by the microbial cultures, further promoting the microbial growth and, hence, laccase enzyme activity. It can also be inferred from the results that microbial cultures exhibited a time-dependent enhancement in their biosorption potential. These results were similar to the findings of Manna et al. [4], who revealed that cadmium (Cd) absorption by Trametes versicolor increased with increased time of exposure. They reported that the fungus absorbed $0.100 \mathrm{mg} \mathrm{g}^{-1}$ of $\mathrm{Cd}$ on the second day of exposure and $0.350 \mathrm{mg} \mathrm{g}^{-1}$ of Cd on the 7th day of exposure. In another study, it was reported that Pseudomonas aeruginosa produced various organic acids in a medium that served as leaching agents and absorbed $53 \%$ of $\mathrm{Cu}$ under optimal conditions [53]. However, in contrast to these results, researchers observed that Streptomyces albidoflavus TN10 was able to recover $68 \%$ of $\mathrm{Cu}$ and $42 \%$ Fe from 
PCBs after an analysis of bioleaching through ICP-MS [54]. Hence, it can be concluded that microbes possess effective and efficient machinery to capture and incorporate the available metal ions in their cellular biomass.

The desorption studies suggested that desorption and recovery of these ions can be performed under acidic conditions. Thus, the retaining ability of $\mathrm{Cu}^{2+}$ and $\mathrm{Fe}^{2+}$ metal ions indicated the remarkable efficiency of these microbial cultures. In the present study, the maximum copper and iron recovery efficiency was recorded for Pleurotus florida $(18.0 \%$ and $12.4 \%$, respectively) followed by Pseudomonas spp. (16.6\% and $13.6 \%$, respectively) after the desorption of biomass loaded with copper ions. Similar to this study, previously published literature showed the use of a large number of bacteria, fungi, and algae as biosorbent matrixes. Further, it was also reported that the biosorption efficiency depends on the microbial biomass and its composition, which varies between different species [55]. It was observed by other researchers that the fungal mycelial work as efficient biosorbent substrates when the metal concentrations in the experimental milieu are substantially low [56]. Further, their uptake did not exceed $0.24 \mathrm{mmol} / \mathrm{g}$, while bacterial biosorbents have a wider concentration range and their metal uptake was well below $0.87 \mathrm{mmol} / \mathrm{g}$. Desorption and the reuse of the biosorbents are crucial factors for reducing the cost of the overall process. The use of a desorption agent (nitric acid) helps with the desorption of $\mathrm{Cu}^{2+}$ and $\mathrm{Fe}^{2+}$ by hindering the interaction between metals and the binding sites of the biosorbent. In this present research, PCBs (E-waste) were used as the metal ion source, where microbial cultures were adsorbed and used biosorption phenomenon to extract the metal ions. Whereas, in another study [57], researchers used CMC beads, immobilized life, and inactivated biomass of Trametes versicolor and reported that more than $95 \%$ of the adsorbed $\mathrm{Cu}^{2+}, \mathrm{Pb}^{2+}$, and $\mathrm{Zn}^{2+}$ were desorbed from the biosorbents. Aspergillus lentulus was also found to be an efficient biosorbent for the uptake of $\mathrm{Cu}^{2+}$ ions from industrial effluents [58].

The SEM studies showed the formation of aggregates by the microbial cells around the deposits, which were probably formed due to the etching of heavy metals on the PCB surface, followed by ion exchange and precipitation. The possible mechanism of action of the test bacteria may be biosorption [59]. The results of this study are in agreement with the published reports, which showcased the removal of heavy metals through bacterial biomass via an ion exchange mechanism $[60,61]$. Likewise, in another study, researchers also discussed the presence of a rough surface of short rods in SEM, which signifies the occurrence of biosorption [62]. Similar to the results presented for $A$. niger, it was observed that the bioleaching of metals from E-waste circuit boards was efficiently carried out by acidophilic fungi; the presence of precipitated E-waste particles on the surface of the cell wall of Aspergillus niger DDNSI was observed through SEM [63]. The fungus hyphal deposits also indicated deformation and an extended degree of coarseness on their outer surface. Similar hyphal surface coarseness and cell deformation were reported due to the loading of cadmium ions on the surface of two fungal cultures, viz. Paecilomyces lilacinus XLA and Mucoromycote spp. XLC [64]. Another report also indicated the morphological alterations in the fungal hyphae of different strains of Ganoderma lucidum and Volvariella volvaceae in response to incubation with silver and titanium oxide metal salt solutions vis-àvis nanoparticles [20]. Further, the surface of the spores appeared to have played a role as the adsorbent matrix for the heavy metal etching due to a decrease in the $\mathrm{pH}$ of the medium and surroundings [65]. The presence of heavy granular deposits in the SEM image of the sample incubated with the Pleurotus florida indicated etching caused thereof (Figure 2d). The granular deposit appeared to be embedded in the exopolysaccharide matrix secreted by the fungus. A similar study indicated the biosorption of metals by Pleurotus florida from spent mushroom compost, which could be easily seen through the difference in the surface of untreated and treated samples [66]. The smooth surface of the mycelium growth on the spent compost showed that there was biosorption. The growth of Trametes versicolor could be observed as the presence of spores, along with the leached surface of the sample PCB. The porous nature of spores could have helped in the adsorption of the metals leached 
down in the incubating medium. Similar observations on the alteration in the surface topography of the E-waste scrap before and after bioleaching of metal ions by using an Aspergillus niger strain were recorded with a recovery of about $70 \% \mathrm{Cu}$ [67]. Further, it was argued that the spores performed a function as a suitable adsorbent possessing a high surface to volume ratio that helped with binding the $\mathrm{Cr}(\mathrm{VI})$ ions from an aqueous medium.

The SEM-EDS analysis reflected that there was bioleaching of these elements from the surface of PCBs, followed by the biosorption of etched elements by inoculated Pseudomonas spp. microbial culture. The biosorption might have occurred due to the mechanism of complexation, which involved the formation of certain metal complexes with the groups present on the cell wall surface of the bacteria. These results are in agreement with another study in which researchers observed the destruction of mica through the bioleaching of kaolin and quartz sands by Bacillus cereus bacteria [68]. Their results also reflected the decrease in individual silicate minerals through EDX spectra because of their destruction after bioleaching. Researchers revealed decreases in concentrations of metal ions, such as $\mathrm{Cu}, \mathrm{Fe}, \mathrm{Ca}$, and $\mathrm{K}$, in E-waste samples when inoculated with Aspergillus niger and Trametes pubescens $[69,70]$. EDX spectra of the biomass of Macroalgae (Cladophora glomerata) showed that there was an increase in biosorption of manganese and chromium [71].

The protein expression profiling of the screened microbial cultures may be attributed to the leaching of metal ions from E-waste and the sorption of these ions by microbial cultures, which promoted the expression of metal binding genes. Therefore, bioleaching followed by biosorption by the microbial cultures required the expression of several novel proteins that may have diverse roles by acting as a metal ion receptor, transporter, catalyst, and chelator. A similar occurrence of an increased number of protein bands was documented in Aspergillus niger after the absorption of chromium metal ions [72]. The same trend was observed when Bacillus was treated with different concentrations of lead $\left(\mathrm{Pb}^{2+}\right)$ [73]. Lower molecular weight $(<60 \mathrm{kDa})$ bands were observed only in treated cultures, suggesting the promotion of expression of specific proteins in the presence of metal ions. An increased number of protein bands for Coprinus atramentarius were observed in the presence of cadmium ions [64]. In another study, additional protein bands were expressed when Fomitella fraxinea was inoculated in a medium supplemented with different metal ions [74]. This might have been due to the biosorption of metal ions, followed by the binding of those metal ions to the promoter/enhancer region of the metal-protein gene, leading to the enhanced expression of metal-specific genes. Similar reports on the upregulation of metalbinding genes at the transcription level in response to heavy metals, hormones, cytokines, and physiological and environmental stress were published [75]. Similarly, laccase enzymes of molecular weight $71 \mathrm{kDa}$ was noticed via SDS-PAGE for Tramete spolyzona [76] and 34 to $85 \mathrm{kDa}$ for Pleurotus ostreatus [77] in the presence of different metal ions (lead and copper). Certain inducers, such as copper, manganese, iron, heavy metals, 2,6-dimethoxy1,4-benzoquinone, $\mathrm{H}_{2} \mathrm{O}_{2}$, amphotericin $\mathrm{B}$, syringic acid, tannic acid, Tween 80 , soybean oil, aromatic compounds, and microclimatic changes (lower temperature and osmotic pressure) were reported as potential inducers for upregulating the laccase gene expression [78].

\section{Conclusions}

In the present study, the bacterial and fungal cultures were compared for their efficacy for bioleaching and biosorption of heavy metals from PCB E-waste. Both these phenomena have not been elucidated in any other previous study to compare the overall efficiency of the bacteria vs. fungal genera. In this study, Pleurotus florida and Pseudomonas spp. exhibited the highest and differential abilities for biosorption and bioleaching of copper and iron, which can be attributed to bio-catalysis for laccase enzymes. These test cultures exhibited variable copper recovery efficiencies, varying between $10.5 \%$ and $18.0 \%$. Based on the above results, it can be identified that in the presence of leached metal ions from E-waste, these microbial cultures exhibited the expression of proteins not observed in the control culture treatment. Our research assessment showed that this technology has promising future opportunities for recovering precious and heavy metals from E-waste. Moreover, 
increased urbanization and industrial activities have emphasized such biological methods since these methods are environmentally safe and economical. However, our study was limited to a laboratory scale. However, for the commercialization of biological method, there would be a need to establish pilot-scale technology for metal recovery, which would require a more integrated and sustainable approach. So far, only a limited number of fungal strains have been associated with biosorption and bioleaching studies. Researchers need to identify and optimize prominent fungal strains with great potential for biosorption and bioleaching and formulate optimal conditions for scaled-up studies to obtain useful results.

Supplementary Materials: The following are available online at https:/ / www.mdpi.com/article/ 10.3390/su14020935/s1, Table S1: Advantages and Disadvantages of conventional and biological methods for efficient metal recovery from e-waste, Table S2: Research studies emphasizing the potential of biological remediation of the E-waste.

Author Contributions: Conceptualization, A.K. and S.S.; methodology, A.K., S.S., F.M.A. and M.M.H.; validation, P.K., A.K., F.M.A. and K.A.A.-E.; formal analysis, P.K. and S.S.; investigation, P.K., A.K. and S.S.; resources, A.K., S.S. and K.A.A.-E.; writing-original draft preparation, P.K. and S.S.; writingreview and editing, A.K., K.A.A.-E. and M.M.H.; visualization, A.K. and S.S.; supervision, A.K. and S.S.; project administration, A.K. and K.A.A.-E.; funding acquisition, M.M.H. All authors have read and agreed to the published version of the manuscript.

Funding: The present study was supported by Taif University's Researchers Supporting Project (TURSP-2020/59), Taif, Saudi Arabia.

Institutional Review Board Statement: Not applicable.

Informed Consent Statement: Not applicable.

Data Availability Statement: Data presented in this manuscript are available upon request from the corresponding author.

Acknowledgments: The authors acknowledge their heartfelt gratitude to the Department of Microbiology, PAU, Ludhiana for financial support. The authors extend their appreciation to the Researchers Supporting Project number (TURSP-2020/59), Taif University, Taif, Saudi Arabia, for providing financial support.

Conflicts of Interest: The authors declare no conflict of interest.

\section{References}

1. Kang, K.D.; Kang, H.; Ilankoon, I.M.S.K.; Chong, C.Y. Electronic waste collection systems using Internet of Things (IoT): Household electronic waste management in Malaysia. J. Clean. Prod. 2020, 252, 119801. [CrossRef]

2. Lang, E.; Gonser, A.; Zadrazil, F. Influence of incubation temperature on activity of ligninolytic enzymes in sterile soil by Pleurotus sp. and Dichomitus squalens. J. Basic Microbiol. 2000, 40, 33-39. [CrossRef]

3. Ayangbenro, A.S.; Babalola, O.O. A new strategy for heavy metal polluted environments: A review of microbial biosorbents. Int. J. Environ. Res. Public Health 2017, 14, 94. [CrossRef]

4. Manna, A.; Sundaram, E.; Amutha, C.; Vasantha, V.S. Efficient removal of cadmium using edible fungus and its quantitative fluorimetric estimation using (Z)-2-(4 H-1, 2, 4-Triazol-4-yl) iminomethylphenol. ACS Omega 2018, 3, 6243-6250. [CrossRef]

5. Rubio, J.; Souza, M.L.; Smith, R.W.L. Overview of flotation as a wastewater treatment technique. Miner. Eng. 2002, 15, 139-155. [CrossRef]

6. Crini, G.; Lichtfouse, E. Advantages and disadvantages of techniques used for wastewater treatment. Environ. Chem. Lett. 2019, 17, 145-155. [CrossRef]

7. Kalia, P.; Zia, A.; Mladenović, D. Examining country development indicators and e-waste under the moderating effect of country development levels and e-waste policy. Int. J. Qual. Reliab. Manag. 2022. [CrossRef]

8. Ariffin, N.; Adullah, M.M.A.B.; Mohd Arif Zainol, M.R.R.; Murshed, M.F.; Hariz-Zain; Faris, M.A.; Bayuaji, R. Review on adsorption of heavy metals in wastewater by using geopolymer. Proc. MATEC Web Conf. 2017, 97, 01093. [CrossRef]

9. Ang, W.L.; Mohammad, A.W. State of the art and sustainability of natural coagulants in water and wastewater treatment. J. Clean. Prod. 2020, 262, 121267. [CrossRef]

10. Parga, J.R.; Valenzuela, J.L.; Cepeda, F. Pressure cynanide leaching for precious metal recovery. JOM 2007, 10, 43-47. [CrossRef]

11. Cheng, Y.W.; Khan, M.R.; Ng, K.H.; Wongsakulphasatch, S.; Cheng, C.K. Harnessing renewable hydrogen-rich syngas from valonization of palm oil mill effluent (POME) using steam reforming technique. Ren. Eng. 2019, 138, 1114-1126. [CrossRef] 
12. Sameera, V.; Naga Deepthi, C.H.; Srinu Bahu, G.; Ravi Teja, V. Role of biosorption in environmental cleanup. J. Microbial. Biochem. Technol. 2011, 1, 1-8. [CrossRef]

13. Uddin, M.K. A review on the adsorption of heavy metals by clay minerals, with special focus on past decade. J. Chem. Eng. 2017, 308, 438-462. [CrossRef]

14. Torres, E. Biosorption: A review of the latest advances. Processes 2020, 8, 1584. [CrossRef]

15. Endeshaw, A.; Birhanu, G.; Zerihun, T.; Misganaw, W. Application of microorganisms in bioremediation-review. J. Environ. Microb. 2017, 1, 2-9.

16. Igiri, B.E.; Okoduwa, S.I.; Idoko, G.O.; Akabuogu, E.P.; Adeyi, A.O.; Ejiogu, I.K. Toxicity and bioremediation of heavy metals contaminated ecosystem from tannery wastewater: A review. J. Toxicol. 2018, 18, 2568038. [CrossRef] [PubMed]

17. Fourest, E.; Roux, J.C. Heavy metal biosorption by fungal mycelial by-products: Mechanisms and influence of pH. Appl. Microbiol. Biotechnol. 1992, 37, 399-403. [CrossRef]

18. Kalia, A.; Singh, S. Myco-decontamination of azo dyes: Nano-augmentation technologies. 3-Biotech 2020, 10, 384. [CrossRef] [PubMed]

19. Liu, X.D.; Thiele, D.J. Oxidative stress induced heat shock factor phosphorylation and HSF-dependent activation of yeast metallothionein gene transcription. Genes. Dev. 1996, 10, 592-603. [CrossRef] [PubMed]

20. Singh, S.; Kuca, K.; Kalia, A. Alterations in growth and morphology of Ganoderma lucidum and Volvariella volvaceae in response to nanoparticle supplementation. Mycobiology 2020, 48, 383-391. [CrossRef]

21. Wu, W.; Liu, X.; Zhang, X.; Zhu, M.; Tan, W. Bioleaching of copper from waste printed circuit boards by bacteria-free cultural supernatant of iron-sulfur-oxidizing bacteria. Bioresour. Bioprocess. 2018, 5, 10. [CrossRef]

22. Trivedi, A.; Hait, S. Efficacy of metal extraction from discarded printed circuit board using Aspergillus tubingensis. In Bioresource Utilization and Bioprocess; Ghosh, S., Sen, R., Chanakya, H., Pariatamby, A., Eds.; Springer: Singapore, 2020; pp. $167-175$.

23. Palmieri, G.; Cennamo, G.; Faraco, V.; Amoresano, A.; Sannia, G.; Giardina, P. A typical laccase isoenzymes from copper supplemented Pleurotus ostreatus cultures. Enzym. Microb. Technol. 2003, 33, 220-230. [CrossRef]

24. Xia, L.; Xu, X.; Zhu, W.; Huang, Q.; Chen, W. A comparative study on the biosorption of $\mathrm{Cd}^{2+}$ onto Paecilomyces lilacinus XLA and Mucoromycote sp. XLC. Int. J. Mol. Sci. 2015, 16, 15670-15687. [CrossRef] [PubMed]

25. Fu, Y.Q.; Li, S.; Zhu, H.Y.; Jiang, R.; Yin, L.F. Biosorption of copper (II) from aqueous solution by mycelial pellets of Rhizopus oryzae. Afr. J. Biotechnol. 2012, 11, 1403-1411.

26. Manavalan, A.; Manavalan, T.; Murugesan, K.; Kutzner, A.; Kalaichelvan, P.T.; Heese, K. Characterization of a solvent, surfactant and temperature-tolerant laccase from Pleurotus sp. MAK-II and its dye decolorizing property. Biotechnol. Lett. 2015, 37, 2403-2409. [CrossRef] [PubMed]

27. Hilson, G.; Monhemius, A.J. Alternatives to cyanide in the gold mining industry what prospects for the future? J. Clean. Prod. 2006, 14, 1158-1167. [CrossRef]

28. Mecucci, A.; Scott, K. Leaching and electrochemical recovery of copper, lead and tin from scarp printed circuit boards. J. Chem. Technol. Biotechnol. 2002, 77, 449-457. [CrossRef]

29. Muammer, K. Recovery of metals and non-metals from electronic wastes by physical and chemical recycling processes. Waste Manag. 2016, 57, 64-90. [CrossRef]

30. Jadhav, U.; Su, C.; Hocheng, H. Leaching of metals from printed circuit board powder by an Aspergillus niger culture supernatant and hydrogen peroxide. RSC Adv. 2016, 6, 43442-43452. [CrossRef]

31. Turner, E.M. Phenoloxidase activity in relation to substrate and development stage in the mushroom, Agaricus bisporus. Trans. Br. Mycol. Soc. 1974, 63, 541-547. [CrossRef]

32. Zhao, X.; Jiang, T.; Du, B. Effect of organic matter and calcium carbonate on behaviors of cadmium adsorption-desorption on/from purple paddy soils. Chemosphere 2014, 99, 41-48. [CrossRef]

33. Laemmli, U.K. Cleavage of structural proteins during the assembly of the head of bacteriophage T4. Nature 1970, 227, 680-685. [CrossRef]

34. Khatri, B.R.; Sodha, A.B.; Shah, M.B.; Tipre, D.R.; Dave, S.R. Chemical and microbial leaching of base metals from obsolete cell-phone printed circuit boards. Sustain. Environ. Res. 2018, 28, 333-339. [CrossRef]

35. Waldir, A.B.; Renata, A.F.; Valdelis, F.A. Characterization of printed circuit boards for metal and energy recovery after milling and mechanical separation. Materials 2014, 7, 4555-4566. [CrossRef]

36. Shah, M.; Tipre, D.; Dave, S. Chemical and biological processes for multi-metal extraction from waste printed circuit boards of computers and mobile phones. Waste Manag. Res. 2014, 32, 1134-1141. [CrossRef]

37. Szałatkiewicz, J. Metals content in printed circuit board waste. Pol. J. Environ. Stud. 2014, 23, $2365-2369$.

38. Janusz, G.; Pawlik, A.; Świderska-Burek, U.; Polak, J.; Sulej, J.; Jarosz-Wilkołazka, A.; Paszczyński, A. 2020. Laccase properties, physiological functions, and evolution. Int. J. Mol. Sci. 2020, 21, 966. [CrossRef] [PubMed]

39. Viswanath, B.; Rajesh, B.; Janardhan, A.; Kumar, A.P.; Narasimha, G. Fungal laccases and their applications in bioremediation. Enzym. Res. 2014, 2014, 1632421. [CrossRef] [PubMed]

40. Rautela, R.; Arya, S.; Vishwakarma, S.; Lee, J.; Kim, K.H.; Kumar, S. E-waste management and its effects on the environment and human health. Sci. Total Environ. 2021, 773, 145623. [CrossRef] [PubMed]

41. Argumedo-Delira, R.; Gómez-Martínez, M.J.; Uribe-Kaffure, R. Fungal tolerance: An alternative for the selection of fungi with potential for the biological recovery of precious metals. Appl. Sci. 2020, 10, 8096. [CrossRef] 
42. Anaya-Garzon, J.; Hubau, A.; Joulian, C.; Guezennec, A.G. Bioleaching of E-waste: Influence of printed circuit boards on the activity of acidophilic iron-oxidizing bacteria. Front. Microbiol. 2021, 12, 669738. [CrossRef]

43. Baldrian, P.; Gabriel, J. Copper and cadmium increase laccase activity in Pleurotus ostreatus. FEMS Microbiol. Lett. 2002, 206, 69-74. [CrossRef] [PubMed]

44. Zhu, C.; Bao, G.; Huang, S. Optimization of laccase production in the white-rot fungus Pleurotus ostreatus (ACCC 52857) induced through yeast extract and copper. Biotechnol. Biotechnol. Equip. 2016, 30, 270-276. [CrossRef]

45. Muthukumarasamy, N.P.; Jackson, B.; Joseph Raj, A.; Sevanan, M. Production of extracellular laccase from Bacillus subtilis MTCC 2414 using agroresidues as a potential substrate. Biochem. Res. Int. 2015, 2015, 765190. [CrossRef]

46. Neifar, M.; Jaouani, A.; Ellouze-Ghorbel, R.; Ellouze-Chaabouni, S.; Penninckx, M.J. Effect of culturing processes and copper addition on laccase production by the white-rot fungus Fomes fomentarius MUCL 35117. Lett. Appl. Microbiol. 2009, 49, 73-78. [CrossRef]

47. Vrsanska, M.; Voberkova, S.; Langer, V.; Palovcikova, D.; Moulick, A.; Adam, V.; Kopel, P. Induction of laccase, lignin peroxidase and manganese peroxidase activities in white-rot fungi using copper complexes. Molecules 2016, 21, 1553. [CrossRef]

48. Fonseca, M.I.; Molina, M.; Antonella, B.; Silvana, F.; Tejerina, M.R.; Velázquez, J.E.; Sadañoski, M.A.; Zapata, P.D. Copper improves the production of laccase by Pleurotus sajor-caju with ability to grow on effluents of the citrus industry. Rev. Int. Contam. Ambient. 2020, 36, 105-114. [CrossRef]

49. Xin, F.; Geng, A. Utilization of horticultural waste for laccase production by Trametes versicolor under solid-state fermentation. Appl. Biochem. Biotechnol. 2011, 163, 235-246. [CrossRef] [PubMed]

50. Yang, D.C.; Blair, K.M.; Salama, N.R. Staying in shape: The impact of cell shape on bacterial survival in diverse environments Microbiol. Mol. Biol. Rev. 2016, 80, 187-203. [CrossRef]

51. Yang, J.; Li, W.; Ng, T.B.; Deng, X.; Lin, J.; Ye, X. Laccases: Production, expression regulation, and applications in pharmaceutical biodegradation. Front. Microbiol. 2017, 16, 832. [CrossRef] [PubMed]

52. Stohs, S.J.; Bagchi, D. Oxidative mechanisms in the toxicity of metal ions. Free. Radic. Biol. Med. 1995, 18, 321-336. [CrossRef]

53. Meshkini, M.; Masoomeh, S.; Mehdi, I.; Amir, A. Bioleaching of copper oxide ore by Pseudomonas aeruginosa. Int. J. Miner. Metall. Mater. 2013, 20, 1130-1133.

54. Kaliyaraj, D.; Rajendran, M.; Angamuthu, V.; Antony, A.R.; Kaari, M.; Thangavel, S.; Venugopal, G.; Joseph, J.; Manikkam, R. Bioleaching of heavy metals from printed circuit board (PCB) by Streptomyces albidoflavus TN10 isolated from insect nest. Bioresour. Bioprocess. 2019, 6, 1-11. [CrossRef]

55. Gadd, G.M. Biosorption: Critical review of scientific rationale, environmental importance and significance for pollution treatment. J. Chem. Technol. Biotechnol. 2009, 84, 13-28. [CrossRef]

56. Cortés, S.; Soto, E.E.; Ordóñez, J.I. Recovery of copper from leached tailing solutions by biosorption. Minerals 2020, $10,158$. [CrossRef]

57. Bayramoğlu, G.; Bektaş, S.; Arıca, M.Y. Biosorption of heavy metal ions on immobilized white-rot fungus Trametes versicolor. J. Hazard. Mater. 2003, 101, 285-300. [CrossRef]

58. Jha, S.; Chauhan, R.; Dikshit, S.N. Fungal biomass as biosorbent for removal of heavy metal from industrial waste water effluent. Asian J. Plant Sci. 2014, 13, 93-97. [CrossRef]

59. Fathollahi, A.; Khasteganan, N.; Coupe, S.J.; Newman, A.P. A meta-analysis of metal biosorption by suspended bacteria from three phyla. Chemosphere 2021, 268, 129290. [CrossRef] [PubMed]

60. Tunali, S.; Çabuk, A.; Akar, T. Removal of lead and copper ions from aqueous solutions by bacterial strain isolated from soil Chem. Eng. J. 2006, 115, 203-211. [CrossRef]

61. Bueno, B.Y.M.; Torem, M.L.; Molina, F.A.L.M.S.; De Mesquita, L.M.S. Biosorption of lead (II), chromium (III) and copper (II) by R. opacus: Equilibrium and kinetic studies. Miner. Eng. 2008, 21, 65-75. [CrossRef]

62. Vishan, I.; Sivaprakasam, S.; Kalamdhad, A. Biosorption of lead using Bacillus badius AK strain isolated from compost of green waste (water hyacinth). Environ. Technol. 2017, 38, 1812-1822. [CrossRef] [PubMed]

63. Marappa, N.; Dhanasekaran, D.; Vinothini, G.; Nooruddin, T. Extraction and recovery of precious metals from electronic waste printed circuit boards by bioleaching acidophilic fungi. Int. J. Environ. Sci. Technol. 2017, 15, 10. [CrossRef]

64. Xie, C.; Hu, L.; Yang, Y.; Liao, D.; Yang, X. Accumulation and tolerance to cadmium heavy metal ions and induction of 14-3-3 gene expression in response to cadmium exposure in Coprinus atramentarius. Microbiol. Res. 2017, 196, 1-6. [CrossRef]

65. Ren, B.; Zhang, Q.; Zhang, X.; Zhao, L.; Li, H. Biosorption of $\mathrm{Cr}$ (VI) from aqueous solution using dormant spores of Aspergillus niger. RSC Adv. 2018, 8, 38157-38165. [CrossRef]

66. Kamarudzaman, A.N.; Chay, T.C.; Amir, A.; Talib, S.A. Biosorption of Mn (II) ions from aqueous solution by Pleurotus spent mushroom compost in a fixed-bed column. Procedia-Soc. Behav. Sci. 2015, 195, 2709-2716. [CrossRef]

67. Kolenčík, M.; Urík, M.; Čerňanský, S.; Molnárová, M.; Matúš, P. Leaching of zinc, cadmium, lead and copper from electronic scrap using organic acids and the Aspergillus niger strain. Fresenius Environ. Bull 2013, 22, 3673-3679.

68. Štyriaková, I.; Štyriak, I.; Nandakumar, M.P.; Mattiasson, B. Bacterial destruction of mica during bioleaching of Kaolin and Quartz sands by Bacillus cereus. World J. Microbiol. Biotechnol. 2003, 19, 583-590. [CrossRef]

69. Michalak, I.; Chojnacka, K.; Witek-Krowiak, A. State of the art for the biosorption process-a review. Appl. Biochem. Biotechnol. 2013, 170, 1389-1416. [CrossRef] 
70. Galhaup, C.; Wagner, H.; Hinterstoisser, B.; Haltrich, D. Increased production of laccase by the wood-degrading basidiomycete Trametes pubescens. Enzym. Microb. Technol. 2002, 30, 529-536. [CrossRef]

71. Michalak, I.; Mironiuk, M.; Marycz, K. A comprehensive analysis of biosorption of metal ions by macroalgae using ICP-OES, SEM-EDX and FTIR techniques. PLoS ONE 2018, 13, e0205590. [CrossRef]

72. Mungasavalli, D.P.; Viraraghavan, T.; Jin, Y.-C. Biosorption of chromium from aqueous solutions by pretreated Aspergillus niger: Batch and column studies. Colloids Surfaces A Physicochem. Eng. Aspects 2007, 301, 214-223. [CrossRef]

73. Xing, S.C.; Chen, J.Y.; Lv, N.; Mi, J.D.; Chen, W.L.; Liang, J.B.; Liao, X.D. Biosorption of lead (Pb $\left.{ }^{2+}\right)$ by the vegetative and decay cells and spores of Bacillus coagulans R11 isolated from lead mine soil. Chemosphere 2018, 211, 804-816. [CrossRef]

74. Park, K.M.; Park, S.S. Purification and characterization of laccase from basidiomycete Fomitella fraxinea. J. Microb. Biotechnol. 2008, 18, 670-675.

75. Tamai, K.T.; Liu, X.; Silar, P.; Sosinowski, T.; Thiele, D.J. Heat shock transcription factor activates yeast metallothionein gene expression in response to heat and glucose starvation via distinct signaling pathways. Mol. Cell. Biol. 1994, 14, 8155-8165. [CrossRef] [PubMed]

76. Chairin, T.; Nitheranont, T.; Watanabe, A.; Asada, Y.; Khanongnuch, C.; Lumyong, S. Biodegradation of bisphenol A and decolorization of synthetic dyes by laccase from white-rot fungus Trametes polyzona. Appl. Biochem. Biotechnol. 2013, 169, 539-545. [CrossRef] [PubMed]

77. Pozdnyakova, N.N.; Turkovskaya, O.V.; Yudina, E.N.; Rodakiewicz-Nowak, Y. Yellow laccase from the fungus Pleurotus ostreatus D1: Purification and characterization. Appl. Biochem. Microbiol. 2006, 42, 56-61. [CrossRef]

78. Shaikh, S.M.; Shaikh, R.U.; Ade, A.B. Protein profiling of Thiobacillus ferrooxidans and Pseudomonas fluorescens mutants during metal extraction. J. Sci. Res. 2018, 10, 61-66. [CrossRef] 